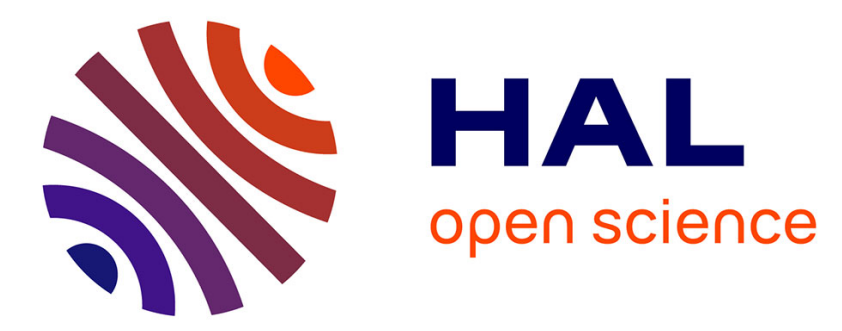

\title{
Application to proteomics to understand and modify meat quality
}

\author{
Mylène Gobert, Thierry Sayd, Philippe P. Gatellier, Veronique
}

Sante-Lhoutellier

\section{- To cite this version:}

Mylène Gobert, Thierry Sayd, Philippe P. Gatellier, Veronique Sante-Lhoutellier. Application to proteomics to understand and modify meat quality. 60. International Congress of Meat Science and Technology (ICoMST), Aug 2014, Punta del Este, Uruguay. 10.1016/j.meatsci.2014.06.035 . hal02744064

\section{HAL Id: hal-02744064 \\ https://hal.inrae.fr/hal-02744064}

Submitted on 3 Jun 2020

HAL is a multi-disciplinary open access archive for the deposit and dissemination of scientific research documents, whether they are published or not. The documents may come from teaching and research institutions in France or abroad, or from public or private research centers.
L'archive ouverte pluridisciplinaire HAL, est destinée au dépôt et à la diffusion de documents scientifiques de niveau recherche, publiés ou non, émanant des établissements d'enseignement et de recherche français ou étrangers, des laboratoires publics ou privés. 


\title{
Application to proteomics to understand and modify meat quality
}

\author{
M. Gobert, T. Sayd, P. Gatellier, V. Santé-Lhoutellier* \\ INRA QuaPA, F 63122 saint Genès Champanelle, France
}

\section{A R T I C L E I N F O}

\section{Article history:}

Received 16 April 2014

Accepted 18 June 2014

Available online 30 June 2014

Keywords:

Proteomics

Meat quality

Sanitory

Nutritional quality

\begin{abstract}
A B S T R A C T
The use of proteomics in the field of meat science has gained in robustness and accuracy. This is consistent with the genomic and bioinformatic tools. Its application to sensorial and technological meat quality traits is discussed as well as the emergence of sanitary and nutritional issue which will grow in a next future.
\end{abstract}

(C) 2014 Elsevier Ltd. All rights reserved.

\section{Introduction}

Meat quality is a broader expression in the meat science which covers different aspects considering the targets. For the consumer, it is clear that a safe product is a prerequisite. Besides that, the qualities searched by consumer are related to their physiological needs and hedonic to fulfill dietary needs but also those the competitiveness of the industry. In the 2000s, several reviews dealing with proteomics focused on technical developments about proteomics, post genomics tools and their limits (Bendixen, 2005; Mullen, Stapleton, Corcoran, Hamill, \& White, 2006), enhancing product quality (Hollung, Veiseth, Jia, Faergestad, \& Hildrum, 2007;) or the species specificity (Paredi, Raboni, Bendixen, de Almeida, \& Mozzarelli, 2012; Picard et al., 2010; Van de Wiel \& Zhang, 2007). In 2013, the review of Paredi et al. (2013) has taken the side to put the use proteomics in meat science in a farm to fork perspective including processing and safety, while the review of Bendixen, Danielsen, Hollung, Gianazza, and Miller (2011) focused on how proteomics would allow to get a better and more efficient production of farm animals. This list is not intended to be fully exhaustive but more for illustrative purposes of the importance of the field of proteomics and its application.

The explosion of publications in the two last decades has profited from the improvements on the reproducibility and robustness of the methods and the analytical tools. A breakthrough occurred with the sequencing of the genome of livestock. In 2004, just three years after the sequence of human genome, the first version of the sequence of the chicken genome was published (Hillier, Miller, Birney, et al., 2004).

\footnotetext{
* Corresponding author.

E-mail address: veronique.sante@clermont.inra.fr (V. Santé-Lhoutellier).
}

This work is the result of over ten years of research in genomics. In 2009, the genome of a female Hereford cow has been sequenced by the Bovine Genome Sequencing and Analysis Consortium, a team of researchers led by the National Institute of Health and the U.S. Department of Agriculture (Elsik et al., 2009). It is one of the largest genomes ever sequenced. In 2012 the genome of a Duroc pig was sequenced. It joined the growing list of pets and livestock whose genome has been sequenced. These results are likely to have a major impact on livestock breeding and for progress in medicine. The pig serves as a research model for human disease because pigs are very similar to human physiology in their behavior and nutritional needs.

In a cell, the protein corresponds to the "end product" of a gene, mercilessly summarizing. However, regulation of gene expression through epigenomic factors, themselves influenced by environmental factors. Proteomics allows the study of the protein content at a given point in time. This holistic view requires the development of high throughput tools and approaches for monitoring gene expression and protein profiles and for determining protein function and interactions. Up to now, proteomic studies have been employed for relating one or two quality traits to a combination of potential biomarkers, trying to gain more knowledge on the physiology and biology of animal, muscle, cell or molecules. Recently, D'Alessandro and Zolla (2013) provided a comprehensive review of on the application of proteomics to farm animals, and especially the muscle to meat conversion, highlighting the emergence of non-proteomics "omics" such as the study of mitochondrial RNAs (miRNAomics, protein post-translational modification PTMomics, metabolomics, lipidomics, ....). Then it is questionable whether to integrate all these data to get the very essence. It must be noted that the mechanisms underpinning the main meat qualities are only partially understood. This review will focus on the recent advances on the classical traits of the meat quality such as those involved in sensorial qualities, 
but also emerging traits such as those involved in sanitary and nutritional traits.

\section{Sensorial quality application}

\subsection{Colour}

The colour of meat is the result of the haeminic pigment content and the oxidoreduction state of the haem iron, highly influenced by the muscle cell environment (metmyoglobin reduction enzyme activity and oxygen consumption). Therefore the meat included its stabilty during storage. Meat colour defect is often considered by consumers as an indication of spoilage and unwholesomeness, leading to rejection of the meat products. Therefore the meat colour is one of the most important traits to be controlled in the meat chain especially for fresh meat. From an economical point of view, the cost of discolouration induced quality was estimated over 1 billion dollar for the meat industry in US (Smith, Belk, Sofos, Tatum, \& Williams, 2000). The meat colour desirable for consumer is firstly species dependent: cherry red for beef, pink for pork and pale pink for poultry, and secondly muscle dependent. The advances in proteomics on this particular trait have shed light on several proteins which contribute to colour stability, mostly chaperones and antioxidant proteins. For example, Sayd et al. (2006) showed that the metabolism of pig muscle leading to darker meat was more oxidative oriented, as it was shown by more abundant mitochondrial enzymes of the respiratory chain, hemoglobin, and chaperone or regulator proteins (HSP27, $\alpha$ B-crystallin, and glucose-regulated protein $58 \mathrm{kDa}$ ). Conversely, enzymes of glycolysis and glutathione S-transferase $\omega$ were overexpressed in the muscle leading to lighter meat. This is consistent with faster postmortem metabolism, namely, acceleration of ATP depletion and $\mathrm{pH}$ fall and subsequent enhanced protein denaturation, well-known to induce discoloration. In beef, the study of Joseph, Suman, Rentfrow, Li, and Beach (2012) showed a higher abundance of peroxiredoxin-2, peptide methionine sulfoxide reductase, and heat shock protein-27 kDa and a positive correlation with colour stability. In other words the color stability of Longissimus could be attributed to the overabundance of antioxidant proteins and chaperones. These authors recommended developing muscle-specific processing strategies to improve beef color. The study of Hwang, Park, Kim, Cho, and Lee (2005) concluded in the same way. Most proteins cited having antioxidant properties, highlighting the major role of oxidation processes in the meat colour and its stability during storage. In addition it puts forward the ability of muscle through its endogenous antioxidant enzymes and antioxidant vitamins to resist to oxidation. In the meat, the oxidation is due to the production of reactive oxygen species such as free radicals. This production is catalysed by transition metals such as copper and especially iron in the case of muscle. In live animals, even in the case of oxidative stress such as handling conditions, the cellular mechanisms of detoxification permit to recover an equilibrium. Indeed in response to the production of ROS (superoxide $\mathrm{O}_{2}^{-}$, hydrogen peroxide $\mathrm{H}_{2} \mathrm{O}_{2}$, hydroxyl radical $\mathrm{OH}^{-}$), the antioxidant system is highly efficient to scavenge or detoxify excess ROS. However within a few hours of animal slaughter, the impact of these free radicals is critical for the muscle cell as its antioxidant protection decreases. The myoglobin oxidation is very linked to lipid oxidation (Baron \& Andersen, 2002). Recent developments in proteomics highlighted the role of reactive aldehydes such as HNE ( 4 hydroxynonenal) or HHE ( 4 hydroxy-hexenal) to make myoglobin adducts mainly via Mickael addition, in other words through the reactivity of their double bond to amine residues. Suman, Faustman, Stamer, and Liebler $(2006,2007)$ used mass spectrometry to identify which histidines were involved via its imidazole residue to the adduction of HNE. This work indicated that for beef, histidines 81 and 88 were preferentially adducted. Moreover the ultimate $\mathrm{pH}$ of the meat combined with the temperature of storage conditions would decrease the potential of HNE to make Mickael adducts. One explanation would be the protonation of imidazole ring at low $\mathrm{pH}$, leading to a nucleophility reduced. Then the histidines of myoglobin would be a target less favorable to HNE adduction.

\subsection{Intramuscular fat}

This trait is of interest for sensorial qualities and marbling with reasonable amounts of intra muscular fat is being sought from now. In farm animal lipids are distributed among in different tissues; however for livestock producer, controlling lipid deposition in muscle is of importance to fit the consumer demand (Fernandez, Monin, Talmant, Mourot, \& Lebret, 1999). The main difficulty is that intramuscular fat has been rarely studied per se but as a component of the determinism of another quality trait: tenderness (Laville et al., 2007). Recently Fuentes, Ventanas, Morcuende, and Ventanas (2013) demonstrated that temporal perception of hardness increased with the IMF content, highligting the key role of lipid in textural properties of meat products. However specific proteomic studies have been carried out to get a deeper knowledge on the promotion of adipogenesis and IMF accumulation instead of cell metabolism (Katsumata, 2011). In this context, the role of dietary lysine level was shown to regulate glucose transporter protein mRNA expression. In addition higher mRNA abundance of peroxisome proliferator-activated receptor $\gamma$, a master regulator of adipogenesis in Longissimus was induced by dietary low lysine. More than $80 \%$ of IMF is stored in adipocytes interspersed in the perimysium and less than 20\% located within cytoplasm of myofibers (Gondret, Guitton, Guillerm-Regost, \& Louveau, 2008). Proteomics was conducted to characterize the adipocytes according to their location (intra muscular, intermuscular, sub cutaneous and perirenal adipose tissue). The comparisons revealed that more than one hundred spots were differently expressed between intra muscular adipocytes and the fat cells derived from the 3 other adipose locations. The proteins involved in lipogenesis (cytosolic malate dehydrogenase and isocitrate dehydrogenase), glycolysis (enolases and aldolase), lipolysis (perilipin), and fatty acid oxidation (long-chain fatty-acyl CoA dehydrogenase) were downregulated in intramuscular adipocytes. These results suggested that the metabolic activity of intramuscular adipocytes is lower than in the other fat tissues. They concluded that triggering adipogenesis rather than cell metabolism per se might be a valuable strategy to control lipid deposition in pig skeletal muscles.

\subsection{Tenderness}

The search for an optimal tenderness generates a broad consensus. A lot of work has been done on the comprehension of the structural and biochemical mechanisms involved in meat tenderness. A remarkable schematic overview of the intricate pathways leading to tenderization was proposed by D'Alessandro and Zolla (2013); however it is difficult, if not impossible to quantify the cascade of hundreds of enzyme reactions, and establishing a hierarchy. The tenderization process starts after animal slaughter by biochemical and physical changes. The first step is the shift from aerobic to anaerobic metabolism to generate energy (ATP Adenosine Triphosphate Dehydrogenase) for maintaining muscle cell homeostasis. However, the APT disappearance causes to the production of protons, i.e. $\mathrm{pH}$ decline and the muscle stiffness. Then the second step includes the action of a set of enzymes involved in proteolysis, oxidation, to mention only the main class of enzymes. The comprehensive review of Lomiwes, Farouk, Wiklund, and Young (2014) on the role of chaperone proteins in the determinism of meat tenderness related their implication in the different events taking place from ante mortem to post mortem and post rigor. For example, their function in unstressed cell is fundamental for polymerization of the actin microfilament as well as the regulation between filaments. Under stress, slaughter can be assimilated to a stressful event; their function is more oriented as a molecular chaperone and anti apoptotic. Most of the studies on tenderness prediction revealed the HSPs as potential biomarkers (Kim et al., 2008; Laville et al., 2009; Polati et al., 2012, to cite a few). 
Apart from HSP, proteins involved in regulating the cell redox state such as peroxiredoxin 1 or 6 have often been proposed as a potential biomarker of beef tenderness. Similarly the protein DJ (PARK7) protecting cells from oxidative stress and death is frequently over expressed in tender meat (Laville et al., 2009). The main other markers belong either to metabolic pathway (glycolytic enzymes) or are proteins involved in the structure and the contraction. In this case, troponin $\mathrm{T}$, alpha actin or heavy (MYH1) and light (MYL1, MYL2, and MYL6B) myosin II chains have altered abundance (Polati et al., 2012). Then identifying contractile proteins provides insights on the target of the proteases. Tenderness is one of the main sensorial traits searched by the consumer whatever the different parts of the world. However the consumer choice is largely dependent of its culture and dietary habit. For example, in Asia, the Korean beef market determines the dollar value of a carcass with marbling score combined with shear force. Therefore the main difficulty is in distinguishing the part of marbling in the overall tenderness. With proteomic approaches, the identification of proteins differently expressed gives rise to a set of potential markers but also to new insights of the metabolic pathways in the muscle cell. Even if there a large consensus on the potential markers of tenderness, generalizing one set of markers from a study to another one may be controversial especially in high marbling meat.

\section{Technological/processing quality application}

The water holding capacity is part of the processing ability of meat. The water holding capacity in muscle, during conversion of muscle to meat and in meat has been well described by Offer and Knight (1989). Mechanical process such as lateral shrinkage and biochemical process such as the post mortem energy metabolism in muscle resulted in a loss of water. In 2004, Hwang et al. (2005) showed that proteomic analysis could predict the loss of water during storage. The molecular mechanisms underlying drip loss are intrinsically linked to the rate and ultimate $\mathrm{pH}$ determinism, driven mainly by the energy metabolism and the regulatory molecular mechanisms associated. Thus the protein markers often identified are LDH and ICDH for energy metabolism, calcium binding proteins (calsequestrin, parvalbumin, ...) and chaperones (Te Pas et al., 2013). Recently Marcos et al. (2013) compared the expression of water soluble proteins of fresh pork Longissimus thoracis from different breed pigs (Duroc, Large White, Landrace, and Pietrain) to identify candidate markers of drip loss using a surface-enhanced laser desorption/ionization time-of-flight mass spectrometry (SELDI-TOFMS). Among the protein peaks detected with CM10 array, 3 peaks were positively correlated with drip loss (peak $\mathrm{m} / z$ 5348, $\mathrm{m} / z$ 12,223 and $m / z$ 12,434). Using a Q10 array, 3 peaks were negatively correlated with drip loss (peak $m / z$ 3201, $m / z 6554$ and $m / z$ 12,119). Both of them were considered as potential soluble protein markers.

Oxidation can affect the processing quality of meat. The review of Lund, Heinonen, Baron, and Estevez (2011) provides insights about the oxidative modifications undergone by muscle proteins. Free radicals attack primarily the double bonds of polyunsaturated fatty acids from lipids. Lipid oxidation then leads to the formation of aldehydes involved in the degradation of flavor of the products, particularly through the development of rancid odor (Byrne et al., 2001). Free radicals attack also the meat protein targeting certain amino acids. Amino acids most susceptible to free radical attack are basic and aromatic amino acids and cysteine (Gatellier et al., 2009; Sante-Lhoutellier, Astruc, Marinova, Greve, \& Gatellier, 2008). The oxidation of proteins, generated insoluble aggregates (Promeyrat et al., 2010), will significantly impact their technological properties as emulsification, gelation or the extraction of proteins of interest.

To ensure optimal final quality of meat and meat products it is essential to have tools to better control these oxidations. Proteomics has been used to identify specific markers for predicting the susceptibility of meat to oxidation. The study of Sayd et al. (2012) aimed to identify specific markers of lipid oxidation generated in meat during refrigerated storage and cooking. For this purpose the early post-mortem sarcoplasmic proteome was analysed and correlated to the level of lipid oxidation. Many proteins could be potential markers of lipid oxidation during meat ageing or cooking, but none of them can serve as marker throughout the complete meat process (from one day to four days of ageing and from raw to cooked meat). For example among the three spots of albumin correlated to lipid oxidation during ageing or after cooking, two of them were negatively correlated while the third one was positively correlated. Significant correlations were found between some proteins that are key regulators of the cellular redox balance (peroxiredoxin and thioredoxin) and the level of lipid oxidation either during ageing or after cooking. Annexins were correlated with lipid oxidation either during ageing (D4) or after cooking (C30). All these correlations were negative, thus indicating a protective effect of annexins against lipid oxidation in meat. Two fatty acid-binding proteins were positively correlated with lipid oxidation. The authors concluded that to predict oxidation generated by processing meat as a whole, the use of a combination of several markers is essential. The identification of early markers of oxidative would allow the meat industry to sort products, according to their oxidative susceptibility to different modes of preserving and/ or processing.

In the meat industry, among the existing huge variety of process, cooking and salting are considered as the most employed. The main difficulty for applying proteomics is linked to the impact of the technological treatments on proteins, modifying their intrinsic properties, leading to fragmentation, changes in solubility or insolubility... However, for cooked ham Pioselli, Paredi, and Mozzarelli (2011) attempted to relate processing conditions such as tumbling and salting to abundance of proteins in the exudates. Tropomyosin, myosin actin and a fragment of serum albumin were identified as markers of the procedure used.

In dry cured ham, peptides are generated in large amounts from structural, contractile and sarcoplasmic proteins contributing to the flavour and the texture of the product. Skrlep et al. (2011) established a proteomic profile according to different genotypes having different degrees of proteolysis during curing. As often, majority proteins were identified as possible biomarkers, such as actin, desmin, and myosin heavy chain fragments associated to structural properties and glycolysis enzymes to soluble properties (Skrlep et al., 2011; Theron et al., 2011). These results gave an overview without an a priori consideration. On the other side, the study of Gallego, Mora, Fraser, Aristoy, and Toldra (2014) focused on the degradation of one specific protein, using nanoliquid chromatography and mass spectrometry in tandem. This protein cypher is located in the sarcomere and implicated in the $\mathrm{Z}$ line structure and muscle integrity. These authors evidenced the action of cathepsins, but more importantly the role of aminopeptidases, carboxypeptidases, di and tri-peptidyl peptidases in the peptides production during the dynamic process of dry cured ham. The peptides produced were characterized in terms of size and sequence but quantification was missing.

\section{Sanitary application}

Consumer is more and more aware of the impact environment on his health and well-being. In a same context, the role of food quality on health is becoming a major concern, where the food origin or the absence of environmental contaminants represents a noteworthy weight in the purchasing decision process. The review of D'Alessandro and Zolla (2012) points out that adulteration is a relevant concern for all kinds of food and especially those with high price like meat. The temptation to replace proteins with non-animal proteins, less expensive to produce, will expand in a next future. Then the challenge will be to ensure the origin of these proteins, for example GMO free, and to control their content.

In the area of authentication, the search for methods for the normative control of raw and processed products is crucial. Authentication of meat origin is of importance considering imported species, religion issue and verification of traceability in a context of worldwide trade 
(Sentandreu \& Sentandreu, 2011). Specific proteomic methods based on the identification of peptide biomarkers specific of a particular meat species and tissue have been developed by Sentandreu, Fraser, Halket, Patel, and Bramley (2010a). The strategy consisted in the enrichment of target proteins in the muscle extract by offgel isoelectric focusing followed by in-solution trypsin digestion of myosin light chain 3 and analysis of species-specific peptide bio-markers by MALDI-TOF MS and LC-ESI. This method was accurate enough to detect the presence of $0.5 \% \mathrm{w} / \mathrm{w}$ contaminating chicken in a mixture with pork meat. The method could be applied to both fresh and cooked meats with quantitative purposes by adding known amounts of marker peptides labeled with stable isotopes. For more similar species, i.e. chicken and turkey, sharing higher sequence homology for myosin light chain 3, Sentandreu, Sentandreu, Fraser, Amat, and Bramley (2010b) identified a specific peptide: a mass value $1010.561 \mathrm{Da}$, corresponding to peptide EAFLLFDR, was specifically found in the chicken sample, whereas the equivalent peptide region in turkey had a mass value of 982.332 Da, corresponds to peptide EAFLLFDK.

Recently, Herrero, Royo, Lago, Vieites, and Espineira (2013) have developed a new method based on fast real time polymerase chain reaction to distinguish not only species but gender (i.e. beef from male or female). This technique combines PCR chemistry with fluorescent probe detection of an amplified product in the same reaction tube. Sequences of cytochrome B and Y-chromosome-specific primers were chosen. Cytochrome B served as a positive control of beef meat. The method developed was validated on meat after industrial treatments which are known to damage DNA leading to a poor DNA extraction. However even with processed products that underwent aggressive treatments, sexing beef was achievable and tangible. Recently a Chinese group related a higher expression of a mitochondrial enzyme, ATP5B which is a catalytic subunit of the mitochondrial ATP synthase complex, associated to a specific breed (Xu et al., 2013). Meishan pigs are known to exhibit a greater oxidative capacity in their muscles, having high fat content and specific expression pattern of myosin heavy chain isoforms (Xu et al., 2009). The oxidative metabolism is therefore the main pathway for ATP and energy synthesis. Compared to Large White, a western pig breed which has been selected for efficient growth rate and leanness, Meishan pigs showed higher expression of the gene ATP5B from the development stage to several months of age. Moreover they identified a mutation, a SNP (G75A), which could be used as a genetic marker of quality trait.

\section{Nutritional application}

Consumers today are well aware of the impact of food on their health. Thus, nutritional quality is becoming an increasingly important factor in food choices, especially in a context of increasing demand for more convenience food. Meat is a source of various micronutrients and before all a good source of proteins, providing all indispensable amino acids. Nevertheless, amino acid composition is not sufficient to determine nutritional quality of a protein source. Indeed the digestibility and the digestion rate impact the whole body metabolism of the absorbed amino acids. Meat processing affect the physico-chemical state of proteins (oxidation, denaturation, aggregation ...) which impact on digestion is unknown. (Bax et al., 2012) demonstrated that cooking had different temperaturedependent effects on the meat protein digestion rate and overall degradation. At $70{ }^{\circ} \mathrm{C}$, the proteins underwent denaturation that enhanced the speed of pepsin digestion by increasing enzyme accessibility to protein cleavage sites. Above $100{ }^{\circ} \mathrm{C}$, oxidation-related protein aggregation slowed pepsin digestion but improved meat protein overall digestibility. The search for potential proteomic markers of digestion parameters was also studied (Bax et al., 2013). A few proteins were identified as potential markers of peak or rate of in vitro digestion. These included enzymes from the Krebs cycle (malate dehydrogenase), detoxification enzymes (S-formylglutathione) and regulatory muscle contraction proteins (slow TnT, calsarcin2). Curiously, more than $40 \%$ of the spots identified which correlate with the in vitro digestion were sarcoplasmic proteins which suggest that protein denaturation due to heat treatment modified the hydrolysis of myofibrillar proteins by digestive enzymes. Evidences were found of important changes in protein solubility in raw meat that could determine the bioaccessibility of digestive proteases to their cleaving site and partly explain the modulation of in vitro digestion parameters. Finally, the results suggested that the force binding actin to myosin in the postmortem actomyosin complex may play a role in the bioaccessibility of the digestive proteases to their substrates. In general terms, any potential protein interaction with either other proteins or muscle compounds such as aldehyde or carbohydrate may impact digestion. During digestion proteins degradation can lead to bioactive peptides and some of them could belong to bioactive components presenting physiological properties such as antihypertensive, antioxidative, immunomodulatory ones (Remond, Savary-Auzeloux, Gatellier, \& SanteLhoutellier, 2008). Sayd, Chambon, Centeno, and Sante-Lhoutellier (2013) quantified the peptide patterns of in vitro digestion of bovine meat cooked at $55{ }^{\circ} \mathrm{C}, 70{ }^{\circ} \mathrm{C}$ and $90{ }^{\circ} \mathrm{C}$. The in vitro digestion consisted in an acid incubation with pepsin (gastric compartment) followed by neutralization and the trypsin and chymotrypsin hydrolysis (intestinal compartment). Samples were collected after $2 \mathrm{~h}$ with pepsin and $2 \mathrm{~h}$ with pancreatic enzymes. The peptides were extracted from the chyle of the gastric and intestinal samples and analysed using on a LTQ Orbitrap coupled to a $\mu$ HPLC DIONEX. The runs were analysed using LC Progenesis software. The peptide identification was realized using Mascot database. In the gastric compartment, most of the peptides identified came from metabolic proteins (enolase, LDH ...). In contrast, the peptides released in the intestinal compartment came mainly from structural proteins such as myosin and from connective tissue such as collagen. These results suggested a delayed proteolysis for proteins less bio accessible in the digestive tract by the proteases. Moreover, the peptides released were modified by the cooking conditions. Another approach for the prediction of nutritional peptides was investigated using integrated in silico methods. Carrera, Canas, and Gallardo (2013) used mass spectrometry tools combined with bioinformatics to relate a prior knowledge of protein content to the liberation of bioactive peptides in gastrointestinal tract. For this purpose, a creation of reference sarcoplasmic proteome from fish was established using a shotgun bottom up approach. In other words, the protein samples were enzymatically digested and the resulting peptides were characterized by mass and charge (M/Z) by LC-MS/MS. This resulted in the identification of a large number of proteins, which were further analysed by gene ontology and functional analysis for the construction of a network of protein biological system. Then groups of proteins sharing common biological and molecular functions and dealing with others groups can be visualized. The prerequisite for such a research is the access to the genome sequence which is nowadays well advanced for the livestock and for fish. Several softwares have been developed to protein classification based on biological functions such as PANTHER program (http://pantherdb.org) and DAVID software for functional domains (http://david.abcc.ncifcrf.gov). The search for proteins interaction can be performed using a program based on between gene interactions named STRING for Search Tool for the Retrieval of Interacting Genes (http:// stringdb.org). In the future more and more in silico approaches are expected to mimic gastrointestinal digestion

\section{Conclusion}

A large variety of proteomic approaches co exist based on isolation of proteins and identification using mass spectrometry and bioinformatics. The most utilized at this time is the 2D electrophoresis, because it is an accessible, inexpensive, and powerful tool for the analysis of protein expression. However shotgun methods based on 1D electrophoresis give promising results due to the generation of larger spectrum of cellular components. Others methods are expanding such as specific chips used in the SELDI spectrometry to cite an example of protein profiling technology. In the future the integration of omics to construct and 
predict metabolic network model is expected to apprehend all the complexity of the biological systems.

\section{References}

Baron, C. P., \& Andersen, H. J. (2002). Myoglobin-induced lipid oxidation: A review. Journal of Agricultural and Food Chemistry, 50, 3887-3897.

Bax, M. L., Aubry, L., Ferreira, C., Daudin, J. D., Gatellier, P., Rémond, D., \& Sante-Lhoutellier $\mathrm{V}$. (2012). Cooking temperature is a key determinant of in vitro meat protein digestion rate: Investigation of underlying mechanisms. Journal of Agricultural and Food Chemistry, 60(10), 2569-2576.

Bax, M. L., Sayd, T., Aubry, L., Ferreira, C., Viala, D., Chambon, C., Remond, D., \& SanteLhoutellier, V. (2013). Muscle composition slightly affects in vitro digestion of aged and cooked meat: Identification of associated proteomic markers. Food Chemistry, 136(3-4), 1249-1262.

Bendixen, E. (2005). The use of proteomics in meat science. Meat Science, 71, 138-149.

Bendixen, E., Danielsen, M., Hollung, K., Gianazza, E., \& Miller, I. (2011). Farm animal proteomics-A review. Journal of Proteomics, 74, 282-293.

Byrne, D. V., Bredie, W. L. P., Bak, L. S., Bertelsen, G., Martens, H., \& Martens, M. (2001). Sensory and chemical analysis of cooked porcine meat patties in relation to warmed-over flavour and pre-slaughter stress. Meat Science, 59, 229-249.

Carrera, M., Canas, B., \& Gallardo, J. M. (2013). The sarcoplasmic fish proteome: pathways, metabolic networks and potential bioactive peptides for nutritional inferences. Journal Proteomics, 78, 221-226.

D'Alessandro, A., \& Zolla, L. (2012). We are what we eat: Food safety and proteomics. Journal of Proteome Research, 11, 26-36.

D'Alessandro, A., \& Zolla, L. (2013). Meat science: From proteomics to integrated omics towards system biology. Journal of Proteomics, 78, 558-577.

Elsik, C. G., et al. (2009). The genome sequence of taurine cattle: A window to ruminant biology and evolution. Science, 324(5926), 522-528.

Fernandez, X., Monin, G., Talmant, A., Mourot, J., \& Lebret, B. (1999). Influence of intramuscular fat content on the quality of pig meat-2. Consummer acceptiability of $\mathrm{m}$. longissimus lumborum. Meat Science, 53, 67-72.

Fuentes, V., Ventanas, J., Morcuende, D., \& Ventanas, S. (2013). Effect of intramuscular fat content and serving temperature on temporal sensory perception of sliced and vacuum packaged dry-cured ham. Meat Science, 93(3), 621-629.

Gallego, M., Mora, L., Fraser, P., Aristoy, M. C., \& Toldra, F. (2014). Degradation of LIM domain binding protein three during processing of Spanish dry cured ham. Food Chemistry, 149, 121-128.

Gatellier, P., Kondjoyan, A., Portanguen, S., Greve, E., Yoon, K., \& Sante-Lhoutellier, V. (2009). Determination of aromatic amino acid content in cooked meat by derivative spectrophotometry: Implications for nutritional quality of meat. Food Chemistry, 114 1074-1078.

Gondret, F., Guitton, N., Guillerm-Regost, C., \& Louveau, I. (2008). Regional differences in porcine adipocytes isolated from skeletal muscle and adipose tissues as identified by a proteomic approach. Journal of Animal Science, 86, 2115-2125.

Herrero, B., Royo, L., Lago, F., Vieites, J., \& Espineira, M. (2013). Authentication of male beef by multiplex fast real-time PCR. Food Additives and Contaminants, Part A, 30, 218-225.

Hillier, L. W., Miller, W., Birney, E., et al. (2004). Sequence and comparative analysis of the chicken genome provide unique perspective on vertebrate evolution. Nature, 432 695-716.

Hollung, K., Veiseth, E., Jia, X., Faergestad, E., \& Hildrum, K. (2007). Application of proteomics to understand the molecular mechanisms behind meat quality. Meat Science, 77 97-104.

Hwang I. H., Park, B. Y. Kim, J. H., Cho, S. H., \& Lee, J. M. (2005). Assessment of postmortem proteolysis by gel-based proteome analysis and its relationship to meat quality traits in pig longissimus. Meat Science, 69, 79-91.

Joseph, P., Suman, S., Rentfrow, G., Li, S., \& Beach, C. M. (2012). Proteomics of musclespecific beef color stability. Journal of Agricultural and Food Chemistry, 60(12), 3196-3203.

Katsumata, M. (2011). Promotion of intramuscular fat accumulation in porcine muscle by nutritional regulation. Journal of Animal Science, 82(1), 17-25

Kim, N. K., Cho, S., Lee, S. H., Park, H. R., Lee, C. S., Cho, Y. M., Choy, Y. H., Yoon, D., Im, S. K., \& Park, E. W. (2008). Proteins in Longissimus muscle of Korean native cattle and their relationship to meat quality. Meat Science, 80, 1068-1073.

Laville, E., Sayd, T., Morzel, M., Blinet, S., Chambon, C., Lepetit, J., Renand, G., \& Hocquette, J. F. (2009). Proteome changes during meat aging in tough and tender beef suggest the importance of apoptosis and protein solubility for beef aging and tenderization. Journal of Agricultural and Food Chemistry, 57, 10755-10764.

Laville, E., Sayd, T., Terlouw, C., Chambon, C., Damon, M., Larzul, C., Leroy, P., Glénisson, J. \& Chérel, P. (2007). Comparison of sarcoplasmic proteomes between two groups of pig muscles selected for shear-force of cooked meat. Journal of Agricultural and Food Chemistry, 55, 5834-5841.

Lomiwes, D., Farouk, M., Wiklund, E., \& Young, O. (2014). Small heat shock proteins and their role in meat tenderness: A review. Meat Science, 96, 26-40.

Lund, M., Heinonen, M., Baron, C., \& Estevez, M. (2011). Protein oxidation in muscle foods: A review. Molecular Nutrition and Food Research, 55, 83-95.
Marcos, B., Gou, P., Guàrdia, M., Hortos, M., Colleo, M., Mach, N., Te Pas, M., Keuning, B., Tibau, J., Gispert, M., \& Arnau, J. (2013). Surface-enhanced laser desorption/ionisation time-of-flight mass spectrometry: A tool to predict pork quality. Meat Science, 95, 688-693.

Mullen, D., Stapleton, P., Corcoran, D., Hamill, R., \& White, A. (2006). Understanding meat quality through the application of genomic and proteomic approaches. Meat Science, $74,3-16$.

Offer, G., \& Knight, P. (1989). The structural basis of water holding in meat. Part 2. Drip loss. In R. Lawrie (Ed.), Developments in meat science, 4. (pp. 173-243). London: Elsevier Applied Science.

Paredi, G., Raboni, S., Bendixen, E., de Almeida, A., \& Mozzarelli, A. (2012). "Muscle to meat" molecular events and technological transformations: The proteomics insights. Journal of Proteomics, 75, 4275-4289.

Paredi, G., Santendreu, M., Mozzarelli, A., Fadda, S., Hollung, K., \& de Almeida, A. (2013). Muscle to meat: New horizons and applications for proteomics on a farm to fork perspective. Journal of Proteomics, 88, 58-92.

Picard, B., Berri, C., Lefaucheur, L., Molette, C., Sayd, T., \& Terlouw, C. (2010). Skeletal muscle proteomics in livestock production. Briefings in Functional Genomics, 9, 259-278.

Pioselli, B., Paredi, G., \& Mozzarelli, A. (2011). Proteomic analysis of pork meat in the production of cooked ham. Molecular Biosystems, 7, 2252-2260.

Polati, R., Menei, M., Robotti, E., Millioni, R., Marengo, E., Novelli, E., Balzan, S., \& Cecconi, D. (2012). Proteomic changes involved in tenderization of bovine Longissimus dorsi muscle prolonged ageing. Food Chemistry, 135, 2052-2069.

Promeyrat, A., Gatellier, P., Lebret, B., Kajak-Siemaszko, K., Aubry, L., \& Sante-Lhoutellier, V. (2010). Evaluation of protein aggregation in cooked meat. Food Chemistry, 121, 412-417.

Remond, D., Savary-Auzeloux, I., Gatellier, P., \& Sante-Lhoutellier, V. (2008). Nutritional properties of meat peptides and proteins: Impact of processing. Science des aliments, 28, 389-401.

Sante-Lhoutellier, V., Astruc, T., Marinova, P., Greve, E., \& Gatellier, P. (2008). Effect of meat cooking on physicochemical state and in vitro digestibility of myofibrillar proteins. Journal of Agricultural and Food Chemistry, 56, 1488-1494.

Sayd, T., Chambon, C., Centeno, D., \& Sante-Lhoutellier, V. (2013). Label-free study of peptides released during in vitro digestion of bovine cooked meat. 2nd International Conference on Food Digestion, March 6-8, Madrid, Spain.

Sayd, T., Chambon, C., Laville, E., Lebret, B., Gilbert, H., \& Gatellier, P. (2012). Early postmortem sarcoplasmic proteome of porcine muscle related to lipid oxidation in aged and cooked meat. Food Chemistry, 136, 2238-2244

Sayd, T., Morzel, M., Chambon, C., Franck, M., Figwer, P., Larzul, C., Le Roy, P., Monin, G., Chérel, P., \& Laville, E. (2006). Proteome analysis of the sarcoplasmic fraction of pig semitendinosous muscle: Implication on meat color development. Journal of Agricultural and Food Chemistry, 54, 2732-2737.

Sentandreu, M. A., Fraser, P. D., Halket, J., Patel, R., \& Bramley, P. M. (2010). A proteomicbased approach for detection of chicken in meat mixes. Journal of Proteome Research, 9, 3374-3383.

Sentandreu, M. A., \& Sentandreu, E. (2011). Peptide biomarkers as a way to determine meat authenticity. Meat Science, 89, 280-285.

Sentandreu, M. A., Sentandreu, E., Fraser, P. D., Amat, C. B., \& Bramley, P. M. (2010b). Peptide biomarkers as a way to differentiate chicken and turkey meat. Proceedings of the 56th ICoMST. Jeju Island (Korea) (pp. 111).

Skrlep, M., Candek-Potokar, M., Mandelc, S., Javorniok, B., Gou, P., Chambon, C., \& SanteLhoutellier, V. (2011). Proteomic profile of dry cured ham relative to PRKAG3 or CAST genotype, level of salt and pastiness. Meat Science, 88, 657-667.

Smith, G., Belk, K., Sofos, J., Tatum, J., \& Williams, S. (2000). Economic implications of improved color stability in beef. In E. A. Decker, C. Faustman, \& C. J. Lopez-Bote (Eds.), Antioxidant in muscle foods: Nutritional strategies to improve quality (pp. 397-426). New York: Wiley Intersci.

Suman, S., Faustman, S., Stamer, S., \& Liebler, D. (2006). Redox instability induced by 4hydroxy-nonenal in porcine and bovine myoglobins at pH5.6 and $4{ }^{\circ} \mathrm{C}$. Journal of Agricultural and Food Chemistry, 54, 3402-3408.

Suman, S., Faustman, S., Stamer, S., \& Liebler, D. (2007). Proteomics of lipid oxidationinduced oxidation of porcine and bovine oxymyoglobins. Proteomics, 7, 628-640.

Te Pas, M., Kruijt, L., Pierzchala, M., Crump, R., Boeren, S., Keuning, E., HGispert, M., Arnau, J., Diestre, A., \& Mulder, H. (2013). Identification of proteomic biomarkers in M Longissimus dorsi as potential predictors of pork quality. Meat Science, 95, 679-687.

Theron, L., Sayd, T., Pinguet, J., Chambon, C., Robert, N., \& Sante-Lhoutellier, V. (2011). Proteomic analysis of semimembranosus and biceps femoris muscles from Bayonne drycured ham. Meat Science, 88(1), 82-90.

Van de Wiel, D. F., \& Zhang, W. L. (2007). Identification of pork quality parameters by proteomics. Meat Science, 77, 46-54.

Xu, Y. J., Jin, M. L., Wang, L. J., Zhang, A. D., Zuo, B. Xu, D. Q Ren, Z. Q Lei, M. G., Mo, X. Y. Li, F. E., Zheng, R., Deng, C. Y., \& Xiong, Y. Z. (2009). Differential proteome analysis in porcine skeletal muscles between Meishan and Large White. Journal Animal Science, $87,2519-2527$

Xu, H., Xu, Y., Liang, X., Wang, Y., Jin, F., Liu, D., Ma, Y., Yuan, H., Song, X., \& Zeng, W. (2013). Porcine skeletal muscle differentially expressed gene ATP5B: Molecular characterization, expression patterns, and association analysis with meat quality traits. Mammalian Genome, 24, 142-150. 